\title{
Evaluation of cookies produced from blends of wheat, cassava and cowpea flours
}

\author{
Olapade Abiodun Adekunle ${ }^{a^{*}}$ And Adeyemo Abimbola Mary ${ }^{a}$ \\ ${ }^{a}$ Department of Food Technology, Faculty of Technology, University of Ibadan, Ibadan Nigeria \\ ${ }^{*}$ Corresponding author \\ aa.olapade@ui.edu.ng \\ TEL: +2348023418735 \\ FAX: +2347060528693
}

Received: 8 October 2013; Published online: 18 October 2014

\begin{abstract}
Cassava (Manihot esculenta Crantz) and cowpea (Vigna unguiculata L. Walp) were processed into flours and used to substitute wheat flour for preparation of cookies. The chemical, including proximate composition and anti-nutritional factors, and functional and pasting properties of the blends were determined. Cookies were produced from the blends with $100 \%$ wheat flour as a control. The antinutritional factors, physical properties and organoleptic attributes of the cookies were evaluated. An increase in the level of cassava flour substitution resulted in a decrease in the protein content of the composite flour. However, addition of cowpea flour resulted in an increase in the protein content. There were significant $(\mathrm{p}<0.05)$ reductions in the studied anti-nutritional factors after baking. Cookies from composite flours were not significantly $(\mathrm{p}>0.05)$ different from the control in overall acceptability. This indicates the feasibility of producing nutritious cookies with desirable organoleptic qualities from cassava, wheat and cowpea composite flour.
\end{abstract}

Keywords: Cassava; Cowpea; Wheat; Cookies; Physico-chemical; Organoleptic qualities

\section{Introduction}

Composite flour can be described as a mixture of several flours obtained from root, tuber, cereal and legume, with or without the addition of wheat flour, which is created to satisfy specific functional characteristics and nutrient composition. Cookies, otherwise known as biscuits, are popular cereal foods, commonly consumed by the populace, especially among the pre-school and school aged children, in Nigeria. Cookies are ready- to-eat, convenient and inexpensive food snacks produced from unpalatable dough that is transformed into a light porous, readily digestible and appetizing product through the application of heat. The principal ingredients are wheat flour, fat, sugar and water, while other op- tional ingredients include milk, salt, flavouring agent, aerating agent and other food additives. Cookies are a rich source of fat, protein and carbohydrate, hence they provide energy and are also a good source of minerals (Kure, Bahago, \& Daniel, 1998). They can be served with soft drinks or tea, and taken between meals like any other snack. In Nigeria, cookie consumption is continually growing and there has been increasing reliance on imported wheat (Akpapunam \& Darbe, 1994).

Wheat flour, the main ingredient for cookies is mainly imported to Nigeria because of unfavourable climatic conditions for its commercial growth. This importation places a considerable burden on the foreign exchange reserve of Nigeria's economy. In an effort to help the 
third world countries reduce their importation, the FAO in 1957 started a study on the technological feasibility of the use of composite flours for the production of cookies, bread and pastry products. Cookies have been suggested as a better use of composite flour than bread due to their ready to eat form, wide consumption, relatively long shelf life and good eating quality (McWatters, Ouedraogo, Resurreccion, Hung, \& Phillips, 2003). The use of composite flours from cereals, legumes and tubers for cookie production is therefore expected to enhance the utilization of local crops as raw materials and improve the nutritive quality of cookies. Composite flours are thus advantageous in the sense that inherent deficiencies of essential amino acids in wheat flour (lysine, tryptophan and threonine) are supplemented from other sources. Bakery products are generally used as a source for incorporation of different nutritionally rich ingredients for their diversification.

Cassava has been identified as the most important root crop in Nigeria in terms of food security, employment creation and income generation for many households (Ugwu \& Nweke, 1996). It is a staple food in many poor and developing countries. Its major limitation is the presence of cyanogenic glycosides (linamarin and lotaustralin). However, several studies have shown that these cyanogenic glycosides are volatile and highly soluble in water and therefore easily eliminated by processing methods such as drying, soaking, and fermentation (Oke, 1994). Some cassava varieties are naturally low in these cyanogenic glycosides thus enhancing their utilization in several food formulations (Ubbor, Akobundu, \& Onwuka, 2006). Cowpea (Vigna unguiculata L. Walp.), an annual legume, is also commonly referred to as southern pea, black eye pea and Crowder pea. Cowpea originated in Africa and is widely grown in Africa, Latin America, South East Asia and in the southern United States. It is chiefly used as a grain crop, for animal fodder, or as a vegetable. There is reported information on the presence of anti-nutritional factors in cowpea but normal household preparation methods have been shown to reduce their concentrations (Olapade \& Aworh, 2012a). However, it is important to find out the extent to which addition of cowpea flour to wheat flour
Table 1: Formulation of flour blends for preparation of cookies

\begin{tabular}{llll}
\hline Sample & $\begin{array}{l}\text { Wheat } \\
\text { Flour }(\%)\end{array}$ & $\begin{array}{l}\text { Cassava } \\
\text { flour }(\%)\end{array}$ & $\begin{array}{l}\text { Cowpea } \\
\text { flour }(\%)\end{array}$ \\
\hline $100 / 0 / 0$ & 100 & 0 & 0 \\
$0 / 100 / 0$ & 0 & 100 & 0 \\
$30 / 50 / 20$ & 30 & 50 & 20 \\
$35 / 35 / 30$ & 35 & 35 & 30 \\
$20 / 70 / 10$ & 20 & 70 & 10 \\
$0 / 80 / 20$ & 0 & 80 & 20 \\
\hline
\end{tabular}

and cassava flour affect the desired quality of the cookies. This study was carried out to determine the effect of incorporation of cowpea and cassava flours, with wheat flour, on the chemical, physical, nutritional and sensory qualities of the cookies.

\section{Materials and Methods}

\subsection{Preparation of Materials}

The TMS-50395 variety of cassava and IT-93129-4 variety of cowpea seeds were obtained from the International Institute of Tropical Agriculture, Ibadan, Nigeria. Commercial wheat flour (Golden Penny, Flourmills of Nigeria Limited) and other ingredients such as granulated sugar and salt (Dangote, Nigeria), baking fat (Unilever, Nigeria), sodium bicarbonate (baking powder) and milk powder (Dano) were purchased from Bodija market in Ibadan, Oyo State, Nigeria. The cassava cultivar was processed into flour as previously described (Oladunmoye, Akinoso, \& Olapade, 2010), while cowpea flour was prepared as previously described by Olapade, Aworh, and Oluwole (2011). The flours were separately packaged in moisture proof polyethylene film and kept at ambient conditions $\left(28 \pm 2{ }^{\circ} \mathrm{C}\right)$ for later use. Composite flours were prepared by blending wheat, cassava and cowpea flours as shown in Table 1 using a Kenwood blender (Model HM400). 


\subsection{Particle Size Distribution Analysis}

The particle size of wheat, cassava and cowpea flours were determined using a set of eight Endicott test sieves (Endicott Ltd., London, UK) ranging from $600 \mu \mathrm{m}$ to $53 \mu \mathrm{m}$ sieve sizes arranged in decreasing order of sieve size. Each sample of $100 \mathrm{~g}$ was placed on the top sieve and mechanically shaken for 15 min on an Endecott's sieve shaker (Endicott Ltd.). The flour retained on each sieve and in the receiver pan was weighed and expressed as the percentage of total flour. Appropriate calculations were made and cumulative graphs were drawn to obtain the average particle size and the most common particle size of each flour sample as described by ANSI/ASAE (2006).

\subsection{Determination of Proximate Composition and Anti-nutritional Factors}

Wheat, cowpea and cassava flours were analyzed for moisture, crude protein, crude fat, crude fiber and ash content according to the official methods of AOAC (2000). The total carbohydrate was calculated by difference. The phytic acid content was measured by a combination of two methods. The extraction and precipitation of phytic acid as ferric phytate was first conducted (Wheeler \& Ferrel, 1971) and then the iron content of the precipitate was determined (Makower, 1970). Tannin content was determined according to the method earlier described (Enujiugha \& Agbede, 2000). Trypsin inhibition activity was determined according to the modified procedure of Kakade, Rackis, Mcghee, and Puski (1974). Total cyanide content was measured using the procedures described by Cooke (1978). All analyses were carried out in triplicate.

\subsection{Determination of Functional and Pasting Properties of the Blends}

Bulk density, water and fat absorption capacities were determined as earlier described (Ola- pade, Akingbala, Oguntunde, \& Falade, 2003). The pasting properties of each sample were determined using a Rapid Visco Analyser (Newport Scientific 1998). The sample (3.5 g) of flour was added into a test canister already containing $25 \mathrm{ml}$ of distilled water, a paddle was placed into the canister and the canister inserted into the instrument. The measurement cycle was initiated by depressing the motor tower of the instrument. The slurry was heated from 50 to 95 ${ }^{\circ} \mathrm{C}$, with a holding time of $2 \mathrm{~min}$, followed by cooling to $50{ }^{\circ} \mathrm{C}$ for a 2 min holding time. The rate of heating and cooling were at a constant rate of $11.25^{\circ} \mathrm{C} / \mathrm{min}$. The canister was then removed on completion of the test and the results were interpreted with the aid of thermocline for windows software provided with the instrument. Peak viscosity, trough, breakdown, final viscosity, set back, peak time and pasting temperature were obtained from the print out. All analyses were carried out in triplicate.

\subsection{Production and Determination of Anti-nutritional factors of Cookies}

Cookies were prepared from the blends according to the recipe shown in Table 2. The sugar and baking fat were creamed together until light and fluffy. Flours were added to the mixture followed by milk, salt and baking powder. The mixture was thoroughly mixed into smooth dough with water. The dough was rolled on a flat wooden surface sprinkled with some flour to a uniform thickness $(5 \mathrm{~cm})$ using a hand roller and cut into predetermined size and shape $(50 \mathrm{~cm}$ diameter $)$ using a biscuit cutter. The dough was arranged in pre-oiled trays and kept at a normal room temperature for $2 \mathrm{~h}$ to allow proper dough leavening and baked in a preheated laboratory oven operating at $220{ }^{\circ} \mathrm{C}$ for $12 \mathrm{~min}$. The biscuits from $100 \%$ wheat flour were used as a control. The cookies were allowed to cool and packed in High Density Polyethylene film and stored at room temperature for subsequent analyses. Phytates, tannin, trypsin inhibitor and total cyanide contents of the cookies were determined as previously de- 
Table 2: Recipe for preparation of cookies

\begin{tabular}{ll}
\hline Ingredient & Quantity \\
\hline Flour $(\mathrm{g})$ & 100 \\
Salt $(\mathrm{g})$ & 1.0 \\
Sugar $(\mathrm{g})$ & 30 \\
Skimmed milk $(\mathrm{g})$ & 7.5 \\
Baking fat $(\mathrm{g})$ & 20 \\
Water $(\mathrm{mL})$ & $76-80$ \\
\hline
\end{tabular}

scribed. All analyses were carried out in triplicate.

\subsection{Determination of Physical Properties of the Cookies}

Physical properties of the cookies were determined according to AACC (2000) methods. Six cookies were weighed on an electronic weighing balance (Mettler, Germany). The diameter was determined by placing six cookies edge to edge using a ruler. The cookies were rotated at an angle of $90^{\circ}$ for duplicate readings. The height was measured by placing six cookies on top of one another using a ruler. The spread factor was expressed as the ratio of the diameter to the thickness of the cookies. All measurements were carried out in triplicate.

\subsection{Sensory evaluation}

The organoleptic evaluation of the coded cookies was carried out by an untrained panel of $30 \mathrm{mem}-$ bers in partitioned booths. Sensory attributes: taste, aroma, crispness, and overall acceptability were evaluated under amber light, whilst appearance was evaluated under bright illuminated light, using a nine point hedonic scale where 1 represents "extremely dislike" and 9 "extremely like".

\subsection{Statistical analysis}

Data were analysed using analysis of variance and the significance of the observed differences between means was separated with Duncan Mul- tiple Range Test procedures using SPSS version 19.0 .

\section{Results and Discussion}

\subsection{Particle Size Distribution}

The particle size distributions of the three main crop flours used in this study are shown in Figure 1. The mean particle size diameters are 127, 129 and $134 \mu \mathrm{m}$ for cowpea, cassava and wheat flours respectively. The most frequently occurring particle size was less than $212 \mu \mathrm{m}$ for all the flour samples. The values obtained in this study were similar to the values reported by Oladunmoye et al. (2010). UNECA (1985) recommended a particle size distribution of about $130 \mu \mathrm{m}$ for flours intended for baking bread, biscuit and other pastry products.

\subsection{Proximate Composition}

The results of the chemical analysis of each crop, the blends and cookies are presented in Table 3. The wheat flour alone contained $10.7 \pm 1.08 \%$ protein, while cassava flour alone contained $4.93 \pm 0.56 \%$, which were similar to the values reported earlier (Oladunmoye et al., 2010). Increase in the levels of cassava flour substitution of wheat flour resulted in a decrease in the protein content progressively, which is attributed to the low protein content of the cassava flour that diluted the protein content of the wheat flour. Addition of $30 \%$ cowpea flour to cassava-wheat flour resulted in the highest protein content of $18.4 \pm 1.03 \%$. The increase in the protein content with cowpea supplementation showed that a nutritious cookie can be produced using cassava flour. The crude protein for cowpea flour was previously reported as 20-26\% (Olapade et al., 2003; Olapade \& Aworh, 2012b). The moisture content ranged from 7.43 to $9.30 \%$ among the blends, which were within the acceptable limits for flours. The highest fat content $(1.80 \pm 0.21 \%)$ was observed in the $35 / 35 / 30$ wheat, cassava and cowpea flour, whilst the fat content for wheat flour was $1.27 \pm 0.05 \%$ and cassava flour was $0.79 \pm 0.04 \%$. Enrichment of cassava-wheat flour with cowpea flour increased 
Cookies from wheat, cassava and cowpea flours $\mid 179$

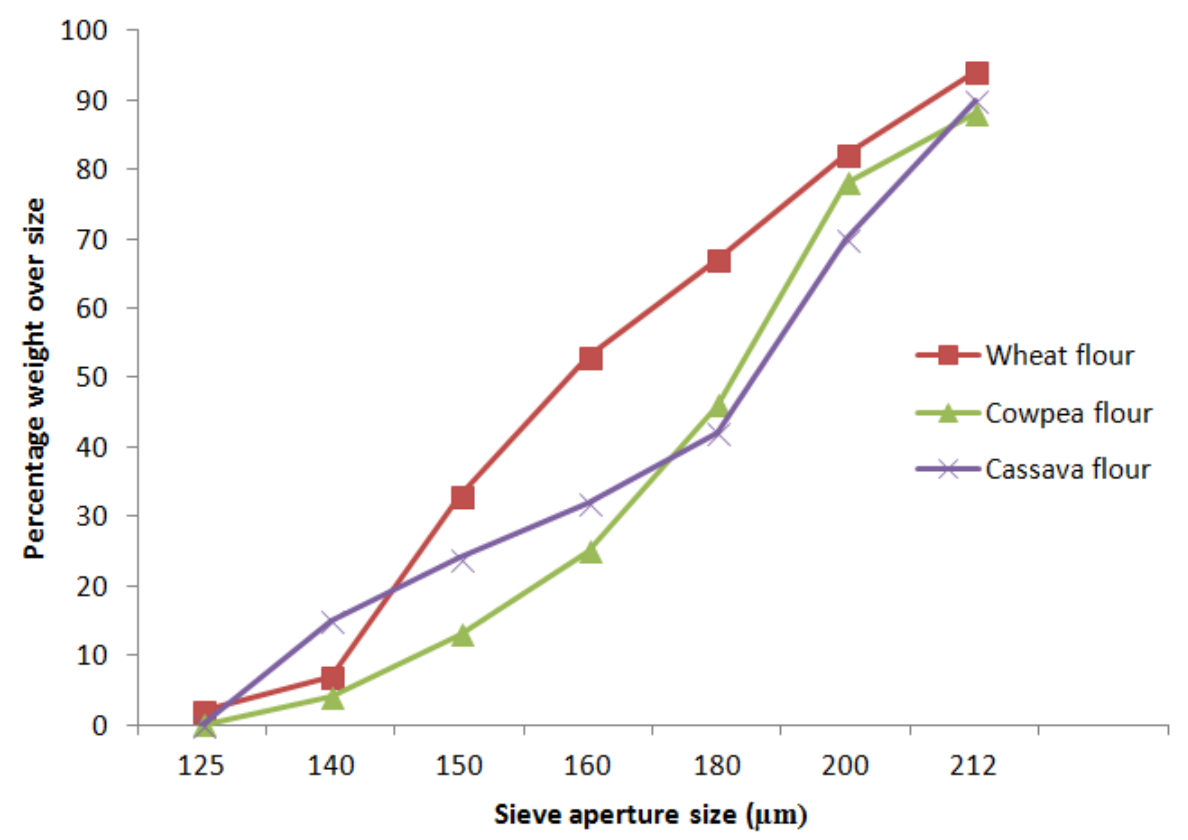

Figure 1: Particle size distribution of the flours

Table 3: Formulation of flour blends for preparation of cookies

\begin{tabular}{lcccccc}
\hline \multirow{2}{*}{ Properties } & \multicolumn{5}{c}{ Wheat/Cassava/Cowpea flours (\%) } \\
\cline { 2 - 7 } & $100 / 0 / 0$ & $0 / 100 / 0$ & $30 / 50 / 20$ & $35 / 35 / 30$ & $20 / 70 / 10$ & $0 / 80 / 20$ \\
\hline Moisture content (\%) & $7.80 \pm 1.04^{b c}$ & $9.04 \pm 1.56^{a}$ & $8.90 \pm 0.98^{a b}$ & $9.30 \pm 1.02^{a}$ & $8.27 \pm 0.08^{a b c}$ & $7.43 \pm 0.89^{c}$ \\
Protein (\%) & $10.7 \pm 1.08^{d}$ & $4.93 \pm 0.56^{f}$ & $14.3 \pm 0.48^{c}$ & $18.4 \pm 1.03^{a}$ & $16.4 \pm 1.58^{b}$ & $7.63 \pm 0.98^{e}$ \\
Fat (\%) & $1.27 \pm 0.05^{b}$ & $0.79 \pm 0.04^{c}$ & $1.67 \pm 0.13^{a b}$ & $1.80 \pm 0.21^{a}$ & $1.60 \pm 0.06^{a b}$ & $1.57 \pm 0.11^{a b}$ \\
Ash (\%) & $3.49 \pm 0.04^{a}$ & $1.73 \pm 0.11^{c}$ & $3.46 \pm 0.23^{a}$ & $3.90 \pm 0.12^{a}$ & $3.17 \pm 0.05^{b}$ & $3.76 \pm 0.12^{a}$ \\
Fibre (\%) & $0.35 \pm 0.02^{c}$ & $0.27 \pm 0.02^{c}$ & $0.63 \pm 0.01^{b}$ & $0.73 \pm 0.03^{a}$ & $0.80 \pm 0.06^{a}$ & $0.77 \pm 0.03^{a}$ \\
Carbohydrate (\%) & $80.3 \pm 2.08^{a}$ & $85.2 \pm 2.85^{a}$ & $75.1 \pm 2.53^{b}$ & $70.6 \pm 1.89^{b}$ & $73.7 \pm 2.01^{b}$ & $83.3 \pm 2.10^{a}$ \\
Phytates (Flour) & $0.52 \pm 0.05^{d}$ & $2.80 \pm 0.07^{c}$ & $3.47 \pm 0.10^{b}$ & $3.17 \pm 0.03^{b}$ & $4.10 \pm 0.06^{a}$ & $3.80 \pm 0.11^{a}$ \\
(mg/kg) (Cookie) & $\mathrm{Nd}$ & $1.00 \pm 0.00^{b}$ & $1.00 \pm 0.06^{b}$ & $1.00 \pm 0.11^{b}$ & $1.50 \pm 0.20^{a}$ & $1.50 \pm 0.02^{a}$ \\
Tannins (Flour) & $5.10 \pm 1.10^{c}$ & $7.53 \pm 1.20^{c}$ & $18.9 \pm 2.54^{b}$ & $18.6 \pm 1.80^{b}$ & $19.7 \pm 1.90^{b}$ & $23.0 \pm 2.10^{a}$ \\
(mg/kg) (Cookie) & $2.50 \pm 0.12^{c}$ & $3.83 \pm 0.85^{b}$ & $8.00 \pm 1.15^{a}$ & $8.00 \pm 0.65^{a}$ & $8.00 \pm 1.05^{a}$ & $8.00 \pm 1.05^{a}$ \\
Trypsin-inhibition (Flour) & $\mathrm{Nd}$ & $2.50 \pm 0.05^{c}$ & $3.67 \pm 0.12^{b}$ & $4.17 \pm 0.03^{a}$ & $4.10 \pm 0.12^{a}$ & $4.00 \pm 0.65^{a}$ \\
(mg/kg) (Cookie) & $\mathrm{Nd}$ & $\mathrm{Nd}$ & $\mathrm{Nd}$ & $\mathrm{Nd}$ & $\mathrm{Nd}$ & $\mathrm{Nd}$ \\
Cyanides (Flour) & $0.02 \pm 0.02^{c}$ & $0.20 \pm 0.06^{a}$ & $0.09 \pm 0.03^{c}$ & $0.12 \pm 0.06^{b}$ & $0.07 \pm 0.03^{c}$ & $0.10 \pm 0.05^{b}$ \\
(mg/kg) (Cookie) & $\mathrm{Nd}$ & $\mathrm{Nd}$ & $\mathrm{Nd}$ & $\mathrm{Nd}$ & $\mathrm{Nd}$ & $\mathrm{Nd}$ \\
\hline
\end{tabular}

Means are of triplicate determinations

Means with the same superscripts within a row are not significantly different $(\mathrm{p}>0.05)$

$\mathrm{Nd}$ - not detected 
the fat content to $1.80 \pm 0.21 \%$ in the $35 / 35 / 30$ wheat, cassava and cowpea flour. The ash content ranged from $1.73 \pm 0.11 \%$ in cassava flour alone to $3.90 \pm 0.12 \%$ in the $35 / 35 / 30$ wheat, cassava and cowpea flour. The fibre content increased with increasing level of substitution of cowpea flour from $0.63 \pm 0.01 \%$ in whole cassava flour to $0.80 \pm 0.06 \%$ in the $35 / 35 / 30$ wheat, cassava and cowpea flour because cowpea seed is relatively high in both ash and fibre (Olapade \& Aworh, 2012a, 2012b). Ash content is an indication of mineral content; hence samples with higher ash content are expected to have a relatively higher mineral content. The values of ash content recorded for the wheat and cassava flours were in line with the values reported by Oladunmoye et al. (2010). The carbohydrate content was highest in cassava flour $(85.2 \pm 2.85 \%)$, while wheat flour contained $80.3 \pm 2.08 \%$. Substitution of cassava-wheat flour led to a decrease in carbohydrate content of the blends.

The major anti-nutritional factors, e.g. Trypsin Inhibitor, Tannin, total cyanide and phytates, were analyzed both in the flours and the corresponding cookies and the results are presented in Table 3. The total cyanide content of the cassava flour $(0.20 \pm 0.06 \mathrm{mg} / \mathrm{kg})$ was the highest, while $0.02 \pm 0.02 \mathrm{mg} / \mathrm{kg}$ was detected in the wheat flour used. The value obtained for cassava flour was lower than the value reported for lafun by Babajide and Olowe (2013). The values ranged from $0.07-0.12 \mathrm{mg} / \mathrm{kg}$, which were below the maximum levels of $2-3 \mathrm{mg} / \mathrm{kg}$ reported by IITA (1998). Cyanide was not detected in the six samples of the cookies, showing effectiveness of the baking process used. Trypsin inhibition activity values ranged from 2.50 to 4.17 $\mathrm{mg} / \mathrm{kg}$, with cassava flour alone having the lowest value. All these values were reduced drastically in the cookies. Previous workers have reported a similar trend in Trypsin inhibition activity for potato flour supplemented with soybean flour (Iwe \& Ngoddy, 1998). Udedibie and Carlini (1998) also confirmed the complete elimination of protease inhibitor after pressure cooking canavaline seeds for $30 \mathrm{~min}$. Phytates and tannin contents were also high in blends with cowpea flour and they were all reduced to minimal levels in the cookies. The tannin content of wheat flour $(5.10 \pm 1.10 \mathrm{mg} / \mathrm{kg})$ was re- duced to $2.5 \pm 0.12 \mathrm{mg} / \mathrm{kg}$ in the cookies. Cassava flour alone with $7.53 \pm 1.20 \mathrm{mg} / \mathrm{kg}$ was reduced to $3.83 \pm 0.85 \mathrm{mg} / \mathrm{kg}$ in the cookies. Sample 20/70/10 with the highest tannin value of $19.7 \pm 1.90 \mathrm{mg} / \mathrm{kg}$ was reduced to $8.0 \pm 1.05 \mathrm{mg} / \mathrm{kg}$ in the cookies. The values of phytates followed the same pattern as tannin. Wheat flour alone had $0.52 \pm 0.05 \mathrm{mg} / \mathrm{kg}$, which was not detected in the cookies. The phytates content of cassava flour $(2.80 \pm 0.07 \mathrm{mg} / \mathrm{kg})$ was reduced to 1.0 $\mathrm{mg} / \mathrm{kg}$ in the cookies. Sample 20/70/10 with a phytates value of $4.10 \pm 0.06 \mathrm{mg} / \mathrm{kg}$ was also reduced to $1.5 \pm 0.02 \mathrm{mg} / \mathrm{kg}$ in the cookies. Processing methods such as soaking, germination and fermentation have been confirmed to reduce the phytates level of legumes (Sandberg, 2002; Egounlety \& Aworh, 2003).

\subsection{Functional and Pasting Properties of the Flour}

The functional and pasting properties of the flours are presented in Table 4. Functional properties were defined as those characteristics that govern the behaviour of constituents of food during processing, storage and preparation as they affect food quality and acceptability. Some of the functional properties that affect the utilization of certain foods are water and fat absorption capacities, bulk density, least gelation concentration, and pasting characteristic. The water absorption and oil absorption capacities increased with addition of cassava flour and cowpea flour when compared with the wheat flour, which had the lowest water absorption capacity $(163 \pm 8 \%)$, while cassava flour had $170 \pm 10 \%$. There were no differences among the blended samples. Both wheat and cassava flours had the same value $(120 \%)$ for fat absorption capacity, which increased with incorporation of cowpea flour in the blends. The result showed that the blend would be useful in bakery products, ground meat, doughnuts and pancakes where oil absorption properties are of prime importance. Water absorption capacity is important in bulking and consistency of product as well as in baking applications (Niba, Bokanga, Jackson, Schlimme, \& Li, 2002). Bulk density values, as shown in Table 4, ranged from 0.64 to $0.69 \mathrm{~g} / \mathrm{ml}$, with whole cassava flour having 
Table 4: Formulation of flour blends for preparation of cookies

\begin{tabular}{|c|c|c|c|c|c|c|}
\hline \multirow{2}{*}{ Properties } & \multicolumn{6}{|c|}{ Wheat/Cassava/Cowpea flours (\%) } \\
\hline & $100 / 0 / 0$ & $0 / 100 / 0$ & $30 / 50 / 20$ & $35 / 35 / 30$ & $20 / 70 / 10$ & $0 / 80 / 20$ \\
\hline Bulk density $\left(\mathrm{g} / \mathrm{cm}^{3}\right)$ & $0.67 \pm 0.12^{a}$ & $0.64 \pm 0.08^{a}$ & $0.69 \pm 0.11^{a}$ & $0.69 \pm 0.12^{a}$ & $0.69 \pm 0.15^{a}$ & $0.69 \pm 0.22^{a}$ \\
\hline Water absorption $(\mathrm{g} / \mathrm{g})$ & $163 \pm 8^{b}$ & $170 \pm 10^{b}$ & $180 \pm 9^{a}$ & $180 \pm 5^{a}$ & $180 \pm 8^{a}$ & $180 \pm 5^{a}$ \\
\hline Fat absorption $(\mathrm{g} / \mathrm{g})$ & $120 \pm 8^{c}$ & $120 \pm 5^{c}$ & $140 \pm 9^{b}$ & $140 \pm 5^{b}$ & $160 \pm 6^{a}$ & $160 \pm 5^{a}$ \\
\hline Peak viscosity (RVU) & $2889 \pm 91^{e}$ & $6221 \pm 102^{a}$ & $2960 \pm 57^{d}$ & $2804 \pm 76^{f}$ & $3794 \pm 102^{c}$ & $4552 \pm 100^{b}$ \\
\hline Trough (RVU) & $1846 \pm 67^{c}$ & $2209 \pm 88^{a}$ & $1787 \pm 90^{d}$ & $1739 \pm 45^{d}$ & $1872 \pm 67^{c}$ & $2076 \pm 78^{b}$ \\
\hline Break down (RVU) & $1043 \pm 26^{e}$ & $4012 \pm 74^{a}$ & $1173 \pm 52^{d}$ & $1065 \pm 54^{e}$ & $1922 \pm 54^{c}$ & $2476 \pm 23^{b}$ \\
\hline Final viscosity (RVU & $3515 \pm 95^{a}$ & $3100 \pm 56^{b}$ & $2729 \pm 78^{e}$ & $2720 \pm 71^{e}$ & $2874 \pm 87^{d}$ & $2977 \pm 56^{c}$ \\
\hline Set back value (RVU) & $1669 \pm 54^{a}$ & $891 \pm 56^{c}$ & $942 \pm 45^{c}$ & $981 \pm 23^{b}$ & $1002 \pm 34^{b}$ & $901 \pm 34^{c}$ \\
\hline Peak time (min) & $6.27 \pm 050^{a}$ & $3.90 \pm 1.0^{f}$ & $5.03 \pm 0.92^{c}$ & $5.17 \pm 0.82^{b}$ & $4.53 \pm 0.55^{d}$ & $4.23 \pm 0.35^{c}$ \\
\hline Pasting temperature $\left({ }^{\circ} \mathrm{C}\right)$ & $69.3 \pm 1.1^{a}$ & $71.8 \pm 2.5^{a}$ & $68.1 \pm 2.8^{a}$ & $73.1 \pm 1.8^{a}$ & $71.8 \pm 2.6^{a}$ & $72.2 \pm 2.0^{a}$ \\
\hline
\end{tabular}

Means are of triplicate determinations

Means with the same superscripts within a row are not significantly different $(\mathrm{p}>0.05)$

the lowest value $(0.64 \pm 0.08 \mathrm{~g} / \mathrm{ml})$. Cowpea flour incorporation resulted in the same value $(0.69$ $\mathrm{g} / \mathrm{ml}$ ) for all the blends. The results are within the reported values for starch foodstuffs (Onuh \& Abdulsalam, 2009). Bulk density is significant in the package design, storage and transport of foodstuff. Low bulk density of the blends could be an advantage in the formulation of baby foods where high nutrient density to low bulk is desired.

There were significant $(\mathrm{p}<0.05)$ differences in the pasting profile of the flour samples (Table 4). The RVA results indicated that the flour had distinct pasting properties compared to the control sample of wheat flour. The pasting temperature of the wheat flour (sample AA) was 69.33 ${ }^{\circ} \mathrm{C}$, while that of cassava flour was $71.80{ }^{\circ} \mathrm{C}$. Sample $0 / 80 / 20$ had a pasting temperature of $72.20{ }^{\circ} \mathrm{C}$, while sample $35 / 35 / 30$ had the highest pasting temperature of $73.10^{\circ} \mathrm{C}$. For peak time, wheat flour had the highest value of $6.27 \mathrm{~min}$ followed by sample $35 / 35 / 30$ with a value of 5.17 min. Cassava flour had the lowest value of 3.9 min. The peak viscosity, which is the ability of starch to swell freely before physical breakdown, ranged from 2804 and 6221.50 RVU for samples $35 / 35 / 30$ and cassava flour respectively. An increase in cassava flour significantly increased the peak viscosity, while an increase in cowpea flour substitution reduced it. Wheat flour alone had a peak viscosity of 2889 RVU, while cassava flour alone had the highest value of 6221RVU. The trough also increased with increase in cassava flour. It was highest in cassava flour with 2209 RVU and lowest in sample 35/35/30 (1739 RVU). Trough is the minimum viscosity value in the constant temperature phase of the RVA profile and it measures the ability of the paste to withstand breakdown during cooling. Wheat flour had a value of 1846 RVU and sample 0/80/20 had a value of 2076 RVU. The breakdown reduced as the cowpea substitution increased from $2476 \mathrm{RVU}$ in $20 \%$ cowpea flour to $1065 \mathrm{RVU}$ in $30 \%$ cowpea flour. The higher the breakdown in viscosity, the lower the ability of the samples to withstand heating and shear stress during cooking (Adebowale \& Lawal, 2004). Wheat flour alone had the lowest breakdown value of 1043 RVU, followed by sample 35/35/30 (1065 RVU). The setback was highest in $100 \%$ wheat flour and it then reduced as the level of wheat flour reduced.

\subsection{Physical Parameters of the Cookies}

All wheat flour cookies exhibited the least spread ratio of 2.32 , while all cassava flour cookies 


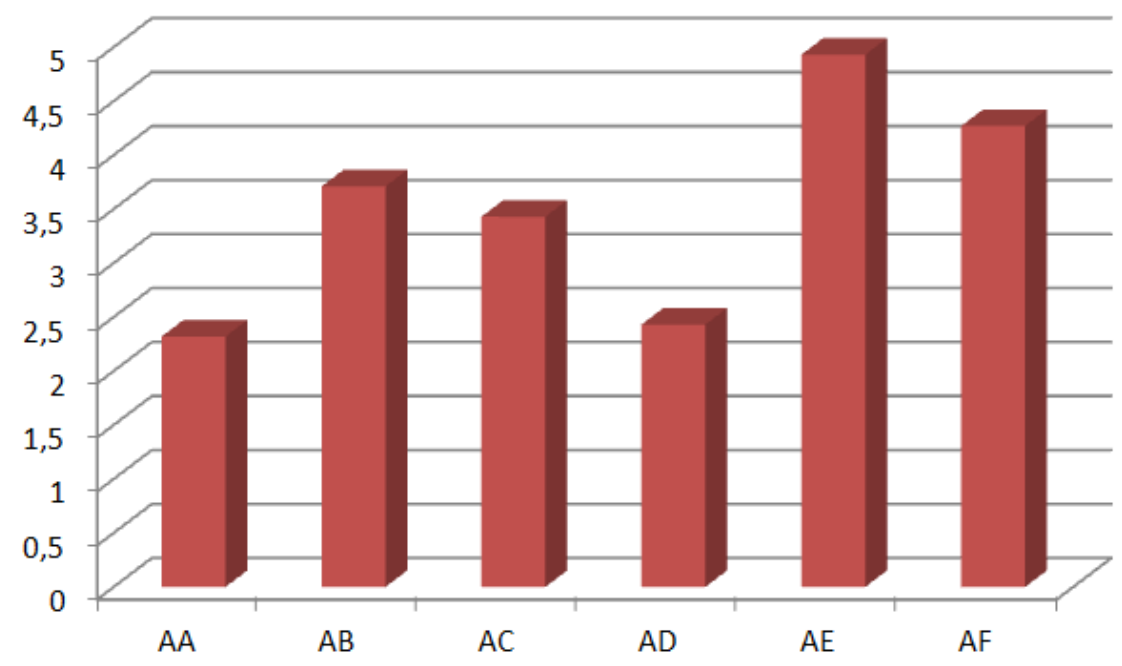

Figure 2: Spread ratio of cookie samples

(AA- wheat flour 100\%, AB- Cassava flour 100\%, AC- Wheat, Cassava, cowpea flour $(30 \%, 50 \%, 20 \%)$, AD- Wheat, Cassava, cowpea flour $(35 \%, 35 \%, 30 \%)$, AE- Wheat, Cassava, cowpea flour $(20 \%, 70 \%, 10 \%)$, AF-Cassava and cowpea flour $(80 \%, 20 \%))$

had a value of 3.71 (Figure 2). The cookies made from 20/70/10 wheat, cassava and cowpea flour had the highest spread ratio value of 4.93. Spread ratio is an indication of ability of the cookie to raise, hence the lower the value the better the ability. The results obtained in this study were similar to the findings reported by Mridula, Gupta, and Manikantan (2007) for wheat/sorghum composite biscuits. Okaka and Isieh (1990) also reported a similar trend in biscuits from wheat and cowpea flours.

\subsection{Sensory evaluation of the cookies}

The mean sensory scores are presented in Table 5 . Taste is an important sensory attribute of any food because of its influence on acceptability. The taste of cookies ranged from 5.75 to 7.94. Except for the cookies from 80/20 cassava/cowpea flour, there were no significant ( $p>0.05)$ differences among the cookie samples. Cookies from a 30/50/20 wheat/cassava/cowpea blend scored highest (7.94), followed by cook- ies from all wheat flour (7.64). There were significant $(\mathrm{p}<0.05)$ differences among the sample means for all crispness scores. An increase in the substitution level of cassava flour resulted in a decrease in crispness scores. Cookie produced from whole cassava scored least in terms of crispness (4.78) while whole wheat cookies had the highest score of 6.96 for crispness. The scores for crispness decreased with increase in the amount of the cassava flour in the blend, and substitution with cowpea flour also contributed to the decrease in crispness, which may be attributed to the high fat absorption capacity of cowpea flour. Aroma is another attribute that influences the acceptance of baked goods even before they are tasted. Substitution of wheat flour with either cassava flour or cowpea flour at different levels did not significantly $(\mathrm{p}<0.05)$ affect the sensory score of aroma. The highest score of 6.80 in aroma was obtained for cookies produced from whole wheat flour (control), while the cookies with an $80 / 20$ cassava/cowpea blend scored least. The brown colour resulting from Maillard reaction is always associated with baked goods. The cookies were significantly $(\mathrm{p}<0.05)$ different in terms of 
Table 5: Organoleptic attributes of cookie samples

\begin{tabular}{lccccc}
\hline Sample & Taste & Colour & Crispness & Aroma & Overall acceptability \\
\hline $100 / 0 / 0$ & $7.64 \pm 1.47^{a b}$ & $7.36 \pm 1.99^{a}$ & $6.96 \pm 2.06^{a}$ & $6.80 \pm 1.96^{a}$ & $7.28 \pm 1.69^{a}$ \\
$0 / 100 / 0$ & $6.76 \pm 1.74^{a b}$ & $6.88 \pm 1.49^{a b c}$ & $4.78 \pm 2.43^{c}$ & $6.48 \pm 1.96^{a}$ & $7.00 \pm 1.69^{a}$ \\
$30 / 50 / 20$ & $7.94 \pm 1.88^{a}$ & $6.44 \pm 2.17^{b c d}$ & $6.00 \pm 1.85^{b}$ & $6.52 \pm 1.79^{a}$ & $7.04 \pm 1.64^{a}$ \\
$35 / 35 / 30$ & $7.28 \pm 2.02^{a b}$ & $7.04 \pm 2.08^{a b}$ & $6.10 \pm 2.14^{a b}$ & $6.28 \pm 2.21^{a}$ & $7.08 \pm 2.02^{a}$ \\
$20 / 70 / 10$ & $6.98 \pm 2.01^{a b}$ & $6.14 \pm 1.96^{c d}$ & $5.76 \pm 2.19^{b}$ & $6.35 \pm 1.88^{a}$ & $6.80 \pm 1.95^{a b}$ \\
$0 / 80 / 20$ & $5.75 \pm 2.61^{b}$ & $5.65 \pm 2.57^{d}$ & $5.33 \pm 2.45^{b c}$ & $6.16 \pm 2.19^{a}$ & $6.16 \pm 2.31^{b}$ \\
\hline
\end{tabular}

Means with the same superscripts within a column are not significantly $(\mathrm{p}>0.05)$ different

colour. The colour of the whole wheat cookie was superior to the other cookies. Cookie from sample 35/35/30 was not significantly $(\mathrm{p}>0.05)$ different from the control cookie in overall acceptability. The observations in the present study were in close agreement with the findings of Akubor and Ukwuru (2003), who studied the effect of soy flour on the functional properties and the potential of soybean and cassava flour blends in cookie production. They observed no significant differences in texture, flavour, taste and overall acceptability of both soy enriched and unenriched flour blend cookies. However, the colour of the soy enriched biscuits was significantly different from the un-enriched biscuit.

\section{Conclusions}

This preliminary study had shown that partial substitutions of wheat flour with cassava and cowpea flours produced protein enriched cookies that compared favourably with whole wheat cookies in acceptability. Though the substitution with cassava flour led to a reduction in protein content of the composite flour, this was counteracted by supplementing with cowpea flour, which resulted in a significant increase in the protein content. Tannins, trypsin inhibitor and total cyanides contents were significantly reduced in the resultant cookies for all the blends.

\section{References}

AACC. (2000). Official methods of analysis. American Association of Cereal Chemists
(10 ${ }^{\text {th }}$ ed.) The Association INC. St., Paul, Minnesota, USA.

Adebowale, K. O. \& Lawal, O. S. (2004). Comparative study of the functional properties of bambarra groundnut (Voandzeia subterranean), jack bean (Canavalia ensiformis) and mucuna bean (Mucuna pruriens) flours. Food Research International, 37(4), 355-365. doi:10.1016/j.foodres.2004.01.009

Akpapunam, M. A. \& Darbe, J. W. (1994). Chemical-composition and functionalproperties of blends of maize and bambara groundnut flours for cookie production. Plant Foods for Human Nutrition, 46(2), 147-155. doi:10.1007/BF01088767

Akubor, P. I. \& Ukwuru, M. U. (2003). Functional properties and biscuit making potential of soybean and cassava flour blends. Plant Foods for Human Nutrition, 58(3), 1-12. doi:10.1023 / B : QUAL . 0000040344. 93438.df

ANSI/ASAE. (2006). Method of determining and expressing fineness of feed materials by sieving. American National Standards Institute/American Society of Agricultural and Biological Engineers. ANSI/ASAE S319.3 Feb 03.

AOAC. (2000). Official Methods of Analysis. $17^{t h}$ Ed. Association of Official Analytical Chemists. Suite 4002200 Wilson Boulevard, Arlington, Virginia 22201-3301, USA.

Babajide, J. M. \& Olowe, S. (2013). Chemical, functional and sensory properties of water yam-cassava flour and its paste. 20(2), 903-909. 
Cooke, R. D. (1978). Enzymatic assay for total cyanide content of cassava (Manihotesculenta crantz). Journal of the Science of Food and Agriculture, 29(4), 345-352. doi:10.1002/jsfa.2740290408

Egounlety, M. \& Aworh, O. C. (2003). Effect of soaking, dehulling, cooking and fermentation with rhizopus oligosporus on the oligosaccharides, trypsin inhibitor, phytic acid and tannins of soybean (Glycine $\max$ merr.), cowpea (Vigna unguiculata 1. walp) and groundbean (Macrotyloma geocarpa harms). Journal of Food Engineering, 56 (23), 249-254. $6^{\text {th }}$ Karlsruhe Nutrition Symposium, Karlsruhe, Germany, Oct 21-23, 2001. doi:10.1016/S0260-8774(02)00262-5

Enujiugha, V. N. \& Agbede, J. O. (2000). Nutritional and anti-nutritional characteristics of african oil bean (Pentaclethra Macrophylla Benth) seeds. Applied Tropical Agriculture, 5(1), 11-14.

IITA. (1998). Cassava processing and utilization. International Institute for Tropical Agriculture, Ibadan. Bulletin 28, 16-18.

Iwe, M. O. \& Ngoddy, P. O. (1998). Proximate composition and some functional properties of extrusion cooked soybean and sweet potato blends. Plant Foods for Human $\mathrm{Nu}$ trition, 53(2), 121-132. doi:10.1023 / A : 1008056019865

Kakade, M. L., Rackis, J. J., Mcghee, J. E., \& Puski, G. (1974). Determination of trypsininhibitor activity of soy products - collaborative analysis of an improved procedure. Cereal Chemistry, 51(3), 376-382.

Kure, O. A., Bahago, E. J., \& Daniel, E. A. (1998). Studies on the proximate composition and effect of flour particle size on acceptability of biscuit produced from blends of soyabeans and plantain flours. Namida Tech- Scope Journal, 3, 17-21.

Makower, R. U. (1970). Extraction and determination of phytic acid in beans (PhaseolusVulgaris). Cereal Chemistry, 47(3), 288295.

McWatters, K. H., Ouedraogo, J. B., Resurreccion, A. V. A., Hung, Y. C., \& Phillips, R. D. (2003). Physical and sensory characteristics of sugar cookies containing mixtures of wheat, fonio (Digitaria exilis) and cowpea (Vigna unguiculata) flours. International Journal of Food Science and Technology, 38(4), 403-410. doi:10.1046/j.13652621.2003.00716.x

Mridula, D., Gupta, R. K., \& Manikantan, M. R. (2007). Effect of incorporation of sorghum flour to wheat flour on quality of biscuits fortified with defatted soy flour. American Journal of Food Technology, 2(5), 428-434.

Niba, L. L., Bokanga, M. M., Jackson, F. L., Schlimme, D. S., \& Li, B. W. (2002). Physicochemical properties and starch granular characteristics of flour from various manihot esculenta (cassava) genotypes. Journal of Food Science, 67(5), 1701-1705. doi:10.1111/j.1365-2621.2002.tb08709.x

Okaka, J. C. \& Isieh, M. I. (1990). Development and quality evaluation of cowpeawheat biscuits. Nigerian Food Journal, 8, 56-62.

Oke, O. L. (1994). Eliminating cyanogens from cassava through processing: technology and tradition. In International workshop on cassava safety, 375 (pp. 163-174). Ishs Acta Horticulturae.

Oladunmoye, O. O., Akinoso, R., \& Olapade, A. A. (2010). Evaluation of some physicalchemical properties of wheat, cassava, maize and cowpea flours for bread making. Journal of Food Quality, 33(6), 693-708. doi:10.1111/j.1745-4557.2010.00351.x

Olapade, A. A., Akingbala, J. O., Oguntunde, A. O., \& Falade, K. O. (2003). Effect of processing method on the quality of cowpea (Vigna unguiculata) flour for akara preparation. Plant Foods for Human Nutrition, 58(3), 1-10.

Olapade, A. A. \& Aworh, O. C. (2012a). Chemical and nutritional evaluation of extruded complementary foods from blends of fonio (Digitaria Exilis stapf) and cowpea ( Vigna Unguiculata l. walp) flours. International Journal of Food and Nutrition Sciences, 1(3), 4-9.

Olapade, A. A. \& Aworh, O. C. (2012b). Evaluation of extruded snacks from blends of acha (Digitaria exilis) and cowpea (Vigna unguiculata) flours. Agricultural Engineering International: CIGR Journal, 14(3), 210217. 
Olapade, A. A., Aworh, O. C., \& Oluwole, O. B. (2011). Quality attributes of biscuit from acha (Digitaria exilis) flour supplemented with cowpea (Vigna unguiculata) flour. African Journal of Food Science and Technology, 2(9), 198-203.

Onuh, J. O. \& Abdulsalam, K. O. (2009). Production and evaluation of the physicochemical properties of maize-bambara groundnut 'apula'. Nigerian Food Journal, 27(1), 83-92.

Sandberg, A.-S. (2002). In vitro and in vivo degradation of phytate. In N. R. Reddy \& S. K. Sathe (Eds.), Food phytates (pp. 139155). CRC Press LLC: Boca Raton.

Ubbor, S. C., Akobundu, E. N. T., \& Onwuka, G. I. (2006). Functional properties and cyanide content of starch and flour of selected cassava (Manihot esculenta crantz) mosaic disease (CMD) resistant varieties. Journal of Raw Materials Research, 3, 415.

Udedibie, A. B. I. \& Carlini, C. R. (1998). Questions and answers to edibility problem of the Canavalia ensiformis seeds - a review. Animal Feed Science and Technology, 74(2), 95-106. doi:10.1016/S0377-8401(98) 00141-2

Ugwu, B. O. \& Nweke, F. I. (1996). Determinants of cassava distribution in nigeria. Agriculture Ecosystems 83 Environment, 60(2-3), 139-156. doi:10 . 1016 / S0167 - 8809(96 ) 01085-7

UNECA. (1985). The concept of composite flours: a technical compendium on composite flours. United Nations Economic Commission for Africa, Addis-Ababa.

Wheeler, E. L. \& Ferrel, R. E. (1971). Method for phytic acid determination in wheat and wheat fractions. Cereal Chemistry, 48(3), 312-320. 